\title{
Velocity Components of Currents and Transport Mechanism in the le Meulee Waters, Weh Island, Indonesia
}

\author{
Ulung Jantama Wisha and Ilham
}

\author{
Research Institute for Coastal Resources and Vulnerability, Ministry of Marine Affiars and Fisheries, \\ Republic of Indonesia \\ Jl. Raya Padang-Painan KM. 16, Bungus, Padang, West Sumatera 25245 \\ Email: ulungjantama@gmail.com
}

\begin{abstract}
Weh Island has become an area of significance in which many developments are ongoing. le Meulee region was one of the developed areas where a new fishing port has been built which may impact to coastal instability. This study aims to determine the sea currents regime in the le Meulee waters and its relation to the transport mechanism. Field survey was conducted on March 2017 by which Tide Gauge and ADCP have installed within and without the port, respectively. Flow model was also simulated depicting current patterns for four extreme tidal conditions. The elliptical form of zonal and meridional components of current proves that the tidal current role takes place. The speed of tidal current ranged from $0-0.42 \mathrm{~m} / \mathrm{s}$ and $0-0.85 \mathrm{~m} / \mathrm{s}$ in the bottom and surface, respectively. The most prominent positive value of current components indicates that the transport mechanism is primarily surface ward during both ebb and flood tides. Reflection and diffraction are identified in the simulation testifying that the emergence of the fishing port has changed the hydrodynamic features. We also founded that the low-speed currents induced sediment settling within the jetty, so that it is essential to conduct regular dredging and bathymetry survey in the surrounding port.
\end{abstract}

Keywords: Velocity components of currents, le Meulee waters, flow model, sediment transport

\section{INTRODUCTION}

Massive developments in Infrastructure occurred in coastal area will induce positive and negative impacts (Martínez et al., 2019). The development without environmental approach also becomes the main problem in coastal area. This issue also threats the outermost islands of Indonesia. Many problems emerge due to community structure changes in term of social and environmental aspects. One of the significance areas, which is affected by massive coastal development, is Weh Island (Gemilang and Wisha, 2019).

Weh Island is one of the outermost islands in Indonesia directly bordered by the Indian Ocean, Bengal Bay, and Malacca Strait as well. Water mass circulations around Weh Island are strongly influenced by oceanatmosphere interactions that influence on hydrodynamic characteristics in the Weh Island (llhamsyah et al., 2018; Rizal et al.,
2012). This condition probably is potential to be utilized as the renewable energy conversion (Purba et al., 2014). On the other hand, it also triggers abrasion and accretion in several areas, resulting in vulnerable coastal structures (Dhiauddin and Gemilang, 2018).

Fishery resources in Weh Island are severely wealthy, especially in the le Meulee waters that becomes the center of capture fisheries and aquaculture. This region has tremendous ecosystem structures in which the coral cover is the largest in the Weh Island (Ondara et al., 2019). Unfortunately, the utilization of fishing gear, that was not environmentally friendly (fish bombing) occurred several years ago, damaged the central fisheries impacting ecosystem issues (Wisha and Ondara, 2018a).

In the le Meulee coastal area, A fishing port has been built to support its role as the center of capture fisheries. However, before developing the port, it is important to study 
the characteristics of local hydrooceanography so that the impacts caused by coastal building existence can be appropriately diminished. The emergence of port buildings in the coastal area will induce the potential of erosion and accretion in surroundings. A study of physical oceanography in the le Meulee waters is essential to figure out the transport mechanism changes due to the existence of fishery harbor in the le Meulee waters.

Several previous related studies have been published. Gemilang and Wisha (2018) defined the current-distributed surface temperature within Sabang Bay. While Wisha et al. (2019) studied the influence of oceanography features on controlling aquaculture wastes within Sabang Bay. Edyanto (2008) focused on the physical characteristics of environment in Sabang Port. Overall, studies in Weh Island was focused on Sabang Bay as the center of marine activities. Factually, the other area such as le Meulee, where the coastal area has been explored, was also the area of significance and rarely studied. Thus, this study aims to reveal the sea currents regime in the le Meulee waters and its relation to the transport mechanism. Nevertheless, this study will also determine the characteristics of physical oceanography in the le Meulee coastal waters as a consideration in assessing the advisability of the existing fishery harbor.

\section{MATERIALS AND METHODS}

The field survey was done on March 14 $15^{\text {th }} 2017$ in the le Meulee coastal area. Tide gauge was mounted for 15 days within the port which was representing one cycle of tidal condition (spring and neap). While the Acoustic Doppler Current Profiler (ADCP) was deployed for two days in the southern le Meulee beside the port's jetty which positioned at the 9 meters depth (Figure 1). $A D C P$ will record the vertical current profile in each layer (every $1 \mathrm{~m}$ toward the surface with blanking distance of $0.5 \mathrm{~m}$ ) (Shcherbina et al., 2018).

Tides and currents data were also used in the validation of the flow model developed in this study. Flow model with flexible mesh was simulated by considering the solution of incompressible Reynolds averaged by NavierStokes equations which consist of continuity and momentum equations (Shokri et al., 2018). The results will depict the tidal current features in the form of two-dimensional hydrodynamic model.

For developing a flexible mesh, we used bathymetry data obtained from Research Institute for Coastal Resources and Vulnerability (RICRV)'s field measurement in 2017. While coastline digitation was also used for bordering land boundary in the simulation. We decided the four water boundaries that represented the north, east, west, and south

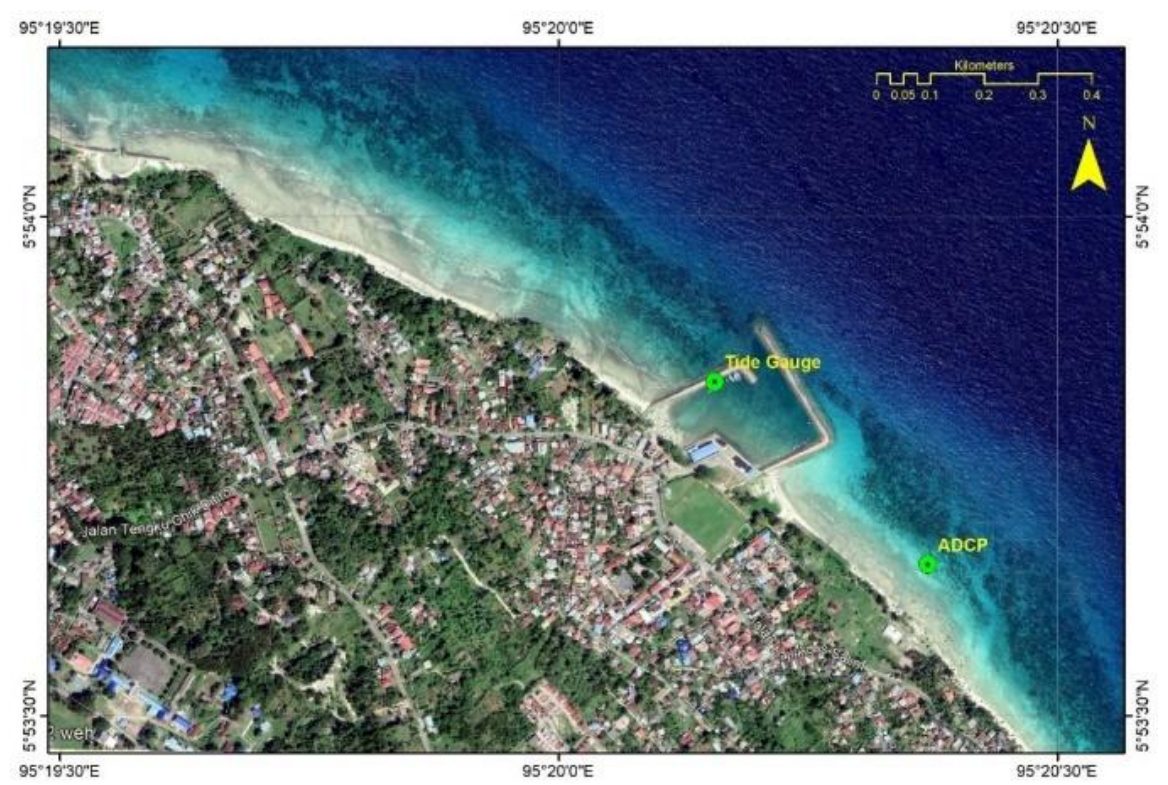

Figure 1. Tide Gauge and ADCP deployment locations and study area 
tidal conditions in the mesh file (Figure 2) which contained the tidal forecast data gained from NAOtide software execution. The model set-up is shown in Table 1.

\section{RESULT AND DISCUSSION}

\section{Tidal current ellipses vertical velocity}

The vertical current velocity characteristics in the le Meulee waters are illustrated in Figure 3. At the depth of 9.5 meters (surface bottom), the current profile is more stable by which the current velocity is the weakest compared to the other layers ranged from $-0.3-0.41 \mathrm{~m} / \mathrm{s}$ and moved northwestward and southeastward. In this layer, many forces take place in hampering the movement of water masses such as bottom friction and higher density, so that the energy transferred from wind-driven current will be diminished resulting in the more stable and relatively weak current movement (Wisha et al., 2015; Wisha et al., 2018c; Bayhaqi et al., 2018). In the water column (5.5-7.5 meters from the surface), the current velocity profile seems sufficiently stable with the higher velocity ranged from $-0.5-0.65 \mathrm{~m} / \mathrm{s}$ which the direction rotated toward west and east. In the surface layer (4.5-2.5 meters beneath the mean sea level), stronger currents are identified by which the speed ranged from $-0.55-0.81 \mathrm{~m} / \mathrm{s}$ with the direction rotates around 3 degrees toward east and west.
Figure 3 also shows the elliptical pattern of current velocity scatter plot proving that the tidal current takes place in the le Meulee waters. The transport mechanism occurred will be evoked by tidal current regime. The semi minor axes of ellipses formed are primarily positive which rotate clockwise. This pattern was induced by the local topographical conditions, Coriolis force, Ekman current and wind pressure differential (Wisha et al., 2019).

The current movement from the surface bottom toward surface water follows the spiral Ekman principle which it proves the vertical transport of water masses-indicating upwelling in the le Meulee waters which is shown by the mainly positive velocity values depicting the water mass movement which tends surface-ward. This dynamic vertical transport mechanism potentially supports the primary productivity enhancement in which the distribution of deposited nutrients will take place inducing biogeochemical cycle disruption in the waters (Wisha and Ondara, 2018b). Previous research published by Ondara et al. (2019) defined that based on the water quality survey, le Meulee waters is categorized into fertile water area where the biodiversity in the le Meulee waters is the greatest compared to other coastal areas in Weh Island (Yulianto et al., 2017; Campbell et al., 2012).

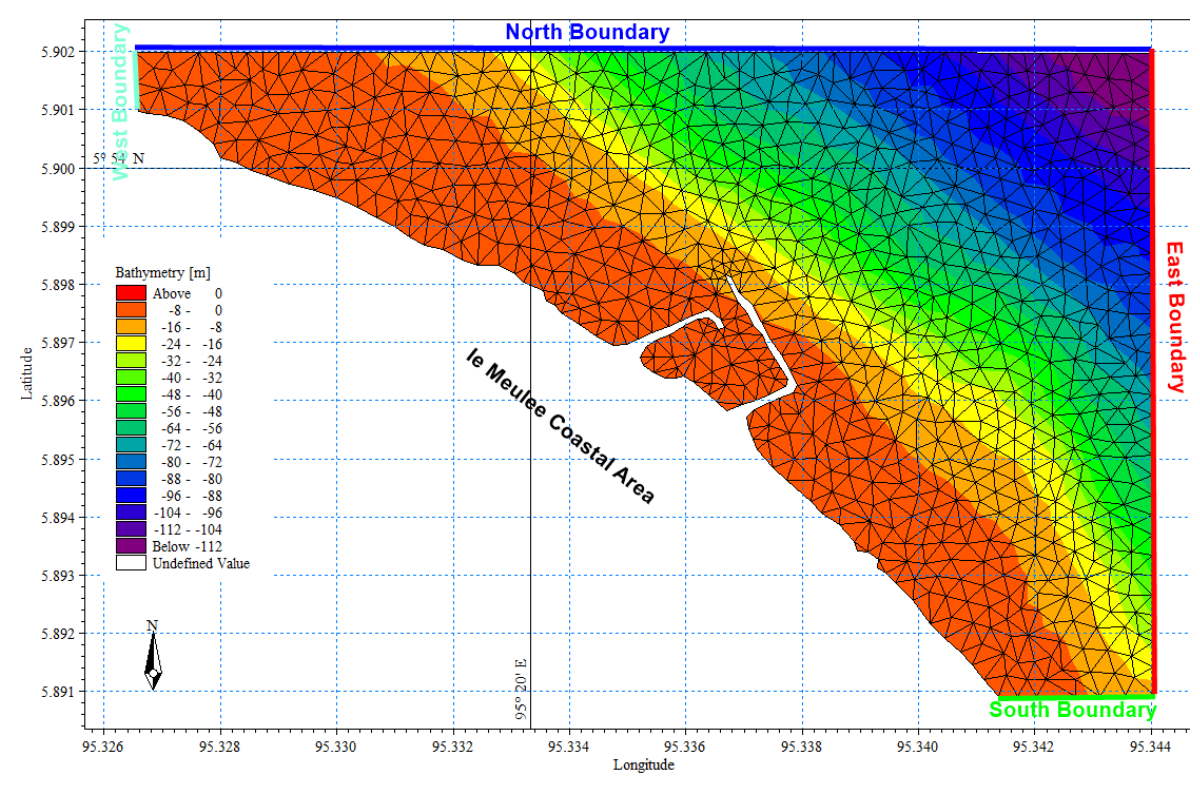

Figure 2. Flexible mesh and boundary conditions 


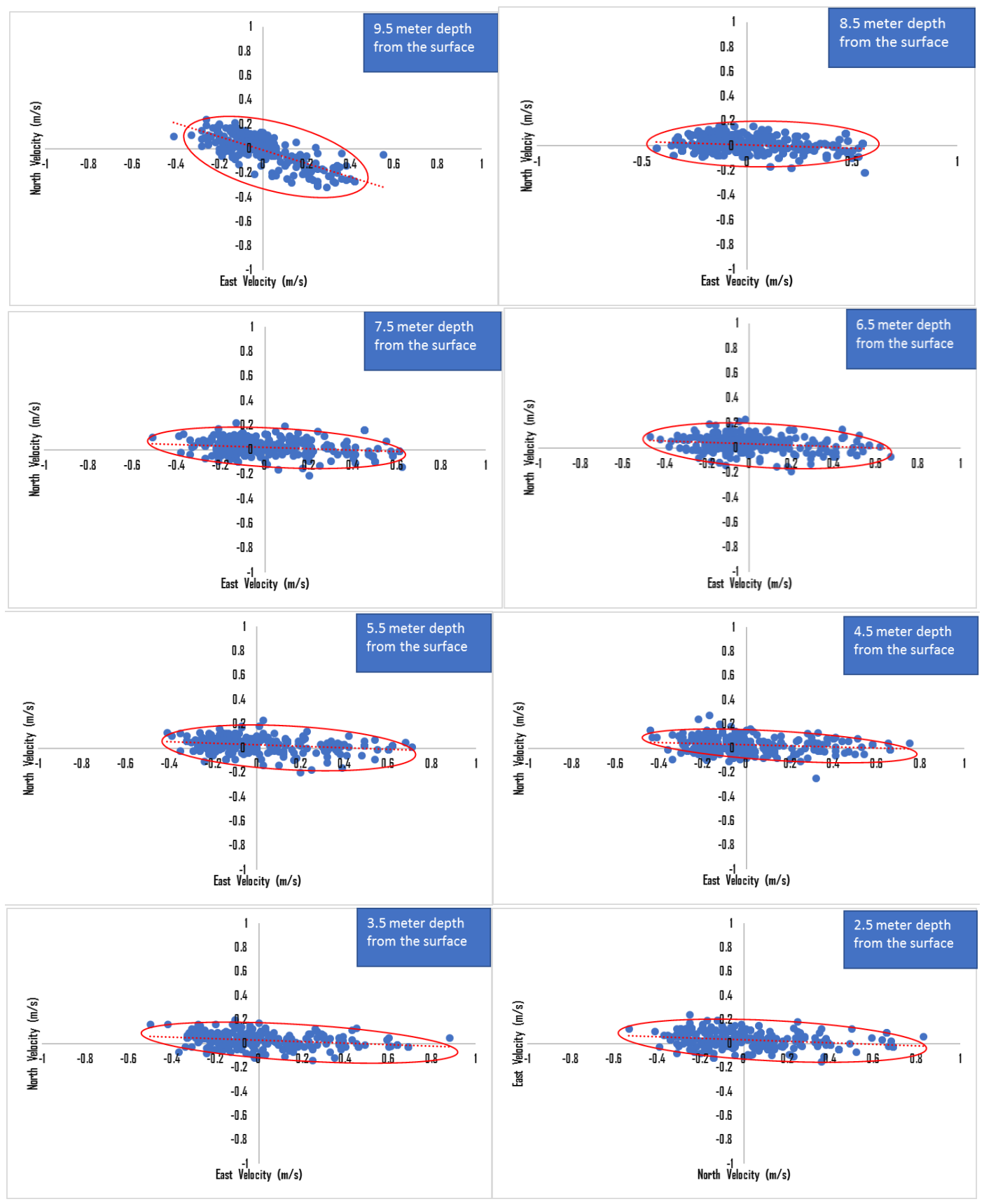

Figure 3. Tidal current elliptical velocity analysis in every layer of depth.

\section{Model Validation}

Due to an approach used in the simulation of tidal current pattern, the results must be validated by comparing the model data with the field survey data (Lazure et al., 2009; Wisha et al., 2018c). In this study, we validated the surface elevation and seacurrent velocity component data.

Figure 4 shows the validation of tidal data in which the similar phases between model and field data are identified, even though the field measurement data seem more erratic during its crest elevations (blue line) in both the high and low tidal conditions. The residual elevation is observed during slack water toward low tidal condition and high tidal condition as well. This randomly slack water condition is tremendously triggered by the wind-induced wave (Hunt et al., 2015). According to Garrett and Kunze (2007) tidal elevation changes followed by the low period of waves will form the arbitrarily erratic 
peak elevation. These disturbances were also possibly caused by the ripples induced by the vessel transportations near the port. Moreover, the RMSE resulted from this comparison was $9.76 \%$. The tidal type according to the tidal analysis was semidiurnal which reiterates approximately every 12 hours, so that during around 24 hours tidal elevation will alter twice with almost the same level but the elevation formed depends on the worked astronomical forces that determine the neap and spring periods. According to previous study, Syaputri et al. (2016) defined that the tidal type of Weh
Island was semidiurnal which the M2 constituent predominated.

The current velocity component data examined were only representing 24 hours simulation adjusted with the ADCP data retrieval which it was only deployed for one day. Figure 5 shows the validation of zonal velocity data by which the zonal velocity ranged from -0.1 up to $0.2 \mathrm{~m} / \mathrm{s}$ and -0.25 up to $0.6 \mathrm{~m} / \mathrm{s}$ for field data and model result, respectively. The RMSE is sufficiently high reaching $15.23 \%$. It is founded that the zonal velocities resulted from the simulation were tremendously higher than the field data

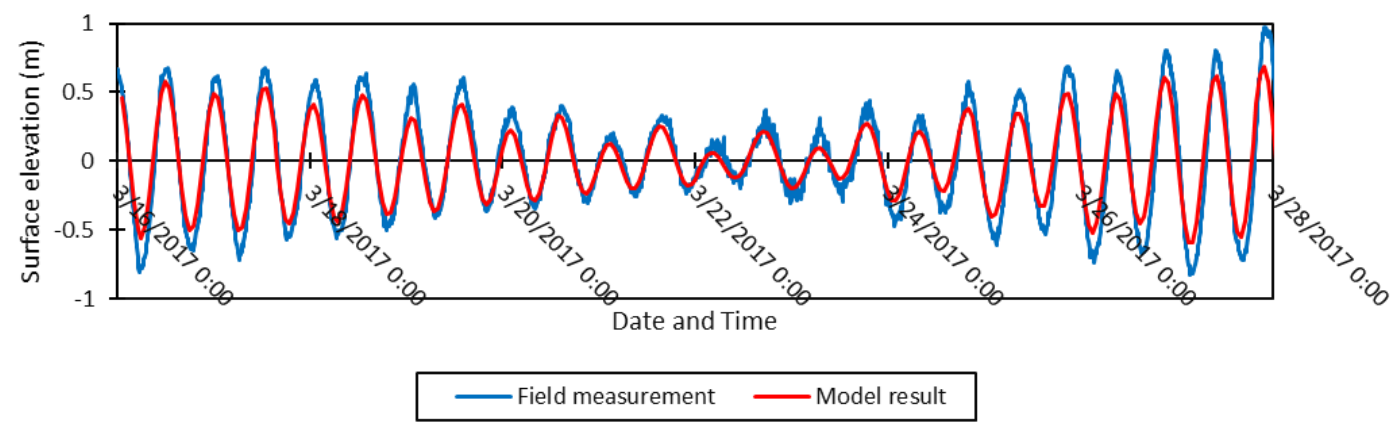

Figure 4. Model validation based on the surface elevation data retrieval.

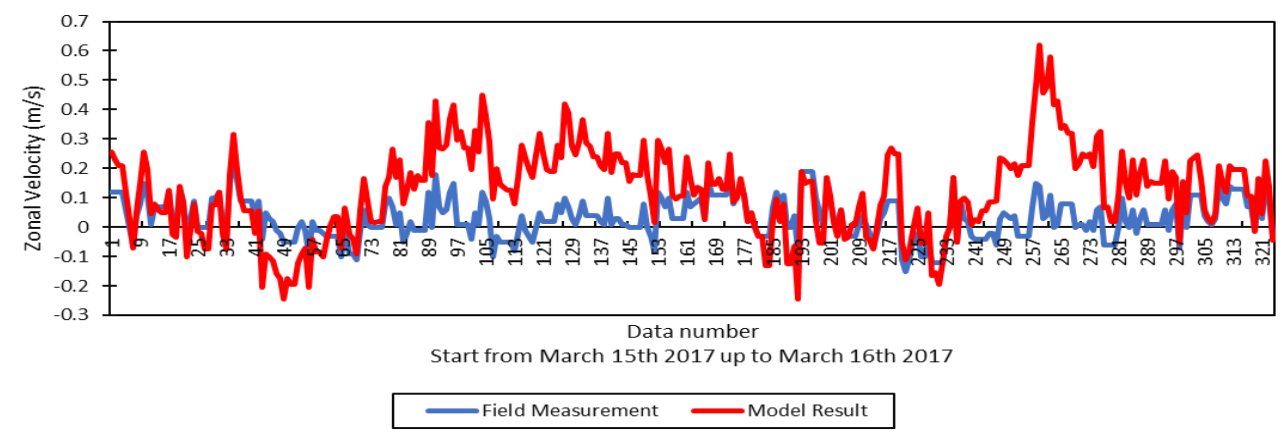

Figure 5. Model validation based on zonal velocity data retrieval.

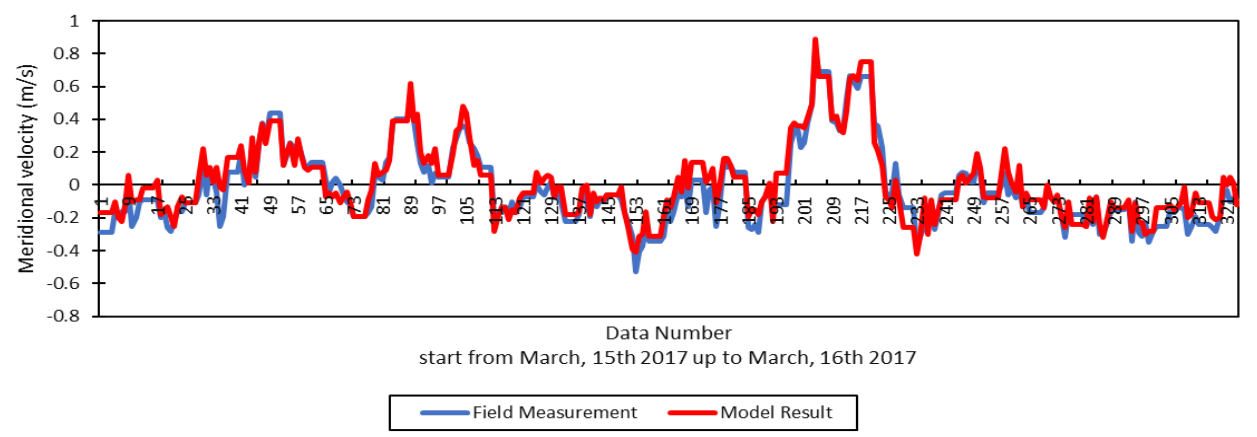

Figure 6. Model validation based on meridional velocity data retrieval. 
which could be caused by some errors in the development of hydrodynamic model, even though the phases were similar.

Generally, the anomalies were identified during the high tidal conditions by which the model approach only considers the higher astronomical forces-induced tidal current during those conditions. That is why the velocity was sufficiently different during high tidal condition, while during low tidal condition, the phases were quite similar with the same velocity ranges (Figure 5). According to Wisha et al. (2015) during the high tidal conditions, the higher elevation took place inducing the higher influence of wind-wave pressures on the surface water, resulting in the more randomly current velocity data.

Different from zonal velocity validation, the meridional velocity data show tremendous similarities both in term of phases and velocity ranges (Figure 6). The velocity ranged from -0.5 up to $0.8 \mathrm{~m} / \mathrm{s}$ and -0.4 up to $0.9 \mathrm{~m} / \mathrm{s}$ for field measurement data and model result, respectively. The higher velocity occurred during the low tidal conditions which oppositely different with the zonal component features. Furthermore, the RMSE obtained was slightly smaller reaching $5.78 \%$ showing that the model developed is severely representing the natural condition of meridional current profile.

The relatively equal between positive and negative fluctuation for both zonal and meridional velocities proves that the transport mechanism is also equal between surfaceward and bottom-ward. Current velocity components have a role in evoking vertical transport in the waters in which the positive value shows the predominantly upper-ward particle movement and vice versa for the negative value (Simatupang et al., 2016). Thus, turbulence and scour events will be reduced shown in Figure 1 that the water visibility is clear without suspended sediment pollution. According to Gemilang and Wisha (2019) the bed-sediment of Weh Island was composed by sand and gravel which is hardly suspended to the water column.

\section{Sea Current patterns in the le Meulee waters}

During the study, the profile of winds was predominated by $0-4 \mathrm{~m} / \mathrm{s}$ speed which the lowest speed (0-1 $\mathrm{m} / \mathrm{s})$ frequently emerged. Northwesterly and southeasterly winds observed. The wind-driven current takes place in the coastal area of le Meulee proved by the same dominant current direction as the wind movements which the speed ranged from 0.1-0.3 m/s. The winddriven current is the main factor in triggering the local transport in the coastal area related to the sediment transport beneath the first breaking-wave crest distributed by longshore current (Burnette and Dally, 2018).

At the high spring tidal conditions (Figure 7A), the current speed ranged from 0 $0.3 \mathrm{~m} / \mathrm{s}$ which the current flows northwestward and southwestward. The current movement in the coastal area of le Meulee closely related to the water mass transfer from Malacca Strait shown in Figure 7A that the dominant current moved from southeast toward northeast with tremendously strong speed reaching $1.11 \mathrm{~m} / \mathrm{s}$. The existence of jetty structures has changed the pattern of currents which it hampered the movement and the direction of current passed by (Wisha et al., 2018c).

At the low spring tidal condition, the current speeds were lower ranging from 0 $0.29 \mathrm{~m} / \mathrm{s}$, while in the deep-sea waters the speed reached $0.99 \mathrm{~m} / \mathrm{s}$ (Figure 7B). The current direction moved predominantly toward north, northwest and northeast. The current flow started to move away sea-ward due to the lower sea surface elevation compared to the surrounding plateau and vice versa during the high tidal condition. According to Rampengan (2009), the reversing current flow is induced by windwave-driven current and commonly called as rectilinear current.

During the neap conditions, the current flow predominantly moved northnorthwesterly and south-southwesterly which rotated around 15 degrees compared to the spring conditions. At the neap high tidal condition, the current speed ranged from 0$0.077 \mathrm{~m} / \mathrm{s}$ while in the deep-sea area, the speed reached $0.36 \mathrm{~m} / \mathrm{s}$ (Figure $7 \mathrm{C}$ ). At the neap low tidal condition, the calmest water flow was observed in which the current speed ranged from $0-0.071 \mathrm{~m} / \mathrm{s}$, while the highest speed was also in the deep-sea area reaching $0.33 \mathrm{~m} / \mathrm{s}$ (Figure $7 \mathrm{C}$ ). The current flow moves reversely in the coastal area. During neap condition, the current profile was 


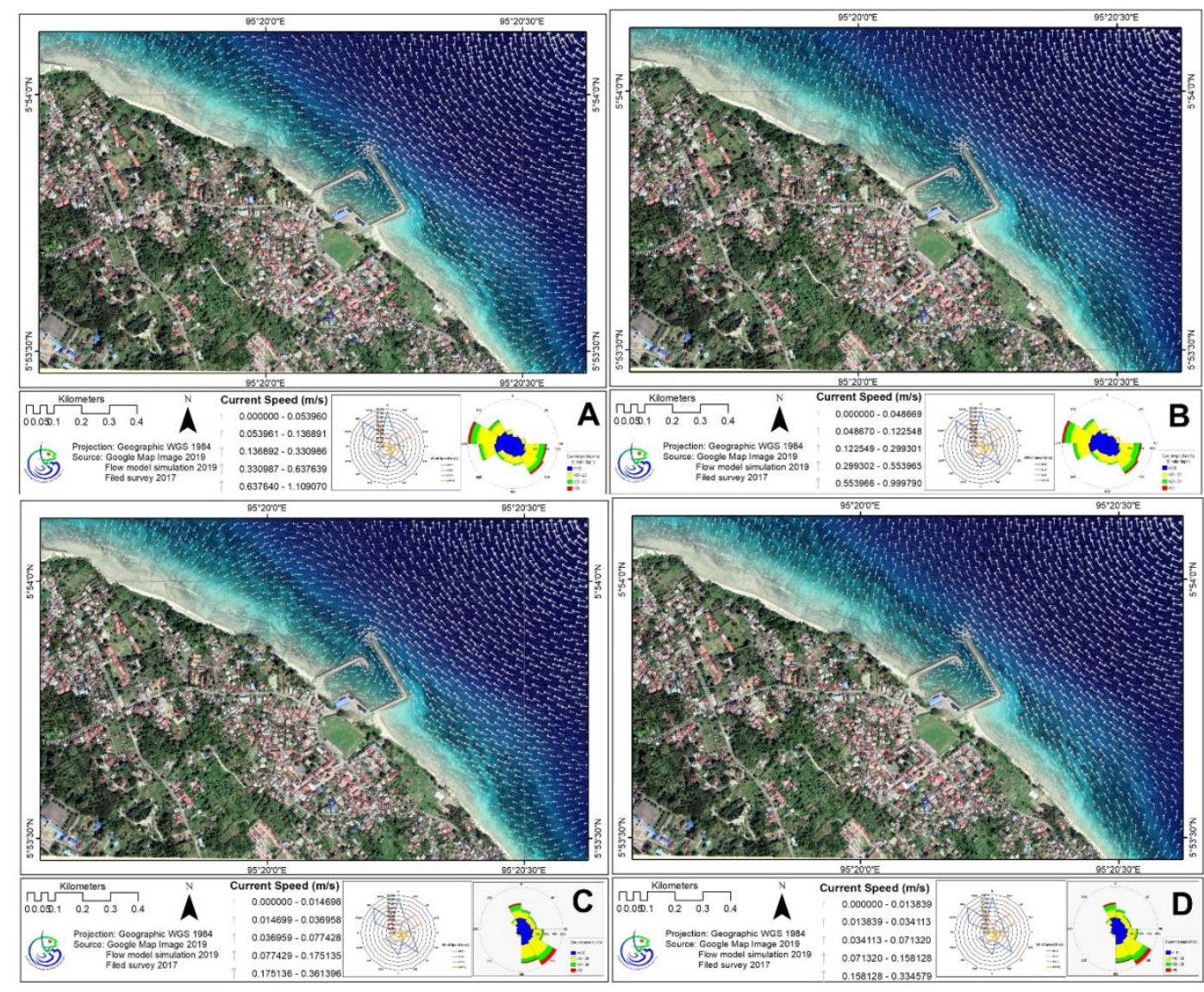

Figure 7. Sea current patterns for four tidal extreme conditions; A. Current pattern during the spring high tidal condition; B. Current pattern during the spring low tidal condition; C. Current pattern during the neap high tidal condition; and D. Current pattern during the neap low tidal condition.

Table 1. Flow model set-up

\begin{tabular}{ll}
\hline Parameter & Implemented in the simulation \\
\hline Time of simulation & Number of time step $=300$ \\
& Time step interval $=3600 \mathrm{sec}$ \\
& Simulation start date $=15 / 03 / 201718.15 \mathrm{PM}$ \\
& Simulation end date $=28 / 03 / 201709.15 \mathrm{AM}$ \\
\hline Mesh boundary & RICRV's bathymetry survey result in 2017 combined with Google \\
& Earth coastline digitation \\
\hline Flood and dry & Drying depth $=0.005 \mathrm{~m}$ \\
& Flooding depth $=0.05 \mathrm{~m}$ \\
& Wetting depth $=0.1 \mathrm{~m}$ \\
\hline Wind forcing & Format $=$ Varying in time, constant in domain. \\
& Neutral pressure $103 \mathrm{hPa}$ \\
& Soft start interval $=0$ sec \\
\hline Boundary condition & Type $=$ Specified level \\
& Format = Varying in time, constant along boundary \\
& Time Series = Tidal forecast with coordinates as follow: \\
& 1. Longitude: 95.326562, Latitude: 5.90148 \\
2. Longitude: 95.335270, Latitude: 5.90198 \\
3. Longitude: 95.344017, Latitude: 5.89645 \\
4. Longitude: 95.342700, Latitude: 5.89092 \\
\hline
\end{tabular}


weaker than the spring period because of the astronomical forces-induced surface elevation changes (Dias et al., 2000). As we discussed in the previous section that the elliptical current velocity component profile shows the tidal current regime predomination in the le Meulee waters, so that the tidal features play a significant role in evoking the current flows which move reversely for ebb and flood tide periods. The wind-driven current also has a special role in triggering the longshore and cross-shore transports which were higher during the spring condition when the astronomical forces-induced tidal condition was taking place(Van Rijn, 2003). Even though the strong current regime takes place in the le Meulee waters, the erosion occurred along the coastline is low. According to Dhiauddin and Gemilang (2018) le meulee coastal area was suffering lowmoderate erosion and coastline changes during 2002-2015.

Compared to the previous related studies in the Weh Island (wisha et al., 2019 and Ondara et al., 2019) where the current speed ranged from 0-0.12 m/s in the Sabang Bay and $0.19-0.3 \mathrm{~m} / \mathrm{s}$ in the Keunekai Waters, the current speed is sufficiently uniform, but different in the dominant direction which depends on the wind regimes (Purba et al., 2014).

According to the model result, diffraction and reflection of current flow take place in the jetty of fishery harbor resulting in the weaker current speed within the jetty ranging from $0-0.05 \mathrm{~m} / \mathrm{s}$ which can cause the higher sedimentation because of the weak transport mechanism in the semi-enclosed water area. This issue potentially impacts on settling tendency and disrupts the shipping lane in the surrounding jetty. Thus, regular dredging and bathymetry survey are necessarily essential to cope with the settling issue within the jetty.

\section{CONCLUSION}

In the le Meulee waters area, the water mass movement is influenced by the winddriven current and tidal. The wind influence is higher in the water column toward surface, while in the surface bottom the influence of winds will be diminished. The vertical transport mechanism is also equal both surface-ward and bottom-ward. The energy transfers from winds induced longshore and cross-shore transport, together with the tidal current influence, the higher transport will take place. The low-speed currents will induce sediment settling within the jetty, so that it is necessarily essential to conduct regular dredging and bathymetry survey in the surrounding port.

\section{ACKNOWLEDGEMENT}

Our deepest gratitude is given to Research Institute for Coastal Resources and Vulnerability (RICRV) for research funding in 2017.

\section{REFERENCES}

Bayhaqi, A., Wisha, U.J. \& Surinati, D., 2018. Modeling Tidal Current on Banten Bay During Transitional Monsoons. J. Segara 14:95-105. doi:10.15578/segara.v14i2.6452

Burnette, C. \& Dally, W.R., 2018. The Longshore Transport Enigma and Analysis of a 10-Year Record of Wind-Driven Nearshore Currents. J. Coast. Res. doi : 10.2112/jcoastres-d-17-00010.1

Campbell, S.J., Cinner, J.E., Ardiwijaya, R.L., Pardede, S., Kartawijaya, T., Mukmunin, A., Herdiana, Y., Hoey, A.S., Pratchett, M.S. \& Baird, A.H., 2012. Avoiding conflicts and protecting coral reefs: Customary management benefits marine habitats and fish biomass. Oryx, 46(4):486-494. doi : 10.1017/S0030605312000348

Dhiauddin, R. \& Gemilang, W.A., 2018. Coastline alteration rate of Weh Island, Aceh Province, Indonesia, IOP Conference Series: Earth and Environmental Science. doi : 10.1088/1755-1315/216/1/012010

Dias, J.M., Lopes, J.F. \& Dekeyser, I., 2000. Tidal propagation in Ria de Aveiro lagoon, Portugal. Phys. Chem. Earth, Part B Hydrol. Ocean. Atmos. 25:369-374. doi : 10.1016/S1464-1909(00)00028-9

Edyanto, C.B.H., 2008. Penelitian aspek Lingkungan Fisik Perairan Sekitar Pelabuhan Sabang. J. Sains dan Technol. Indones. 10:119-128.

Garrett, C., Kunze, E., 2007. Internal Tide Generation in the Deep Ocean. Annu. Rev. Fluid Mech. 39:57-87. doi: 10.1146/annurev.fluid.39.050905.110227 
Gemilang, W.A., Wisha, U.J., 2019. Pengaruh Aktivitas Seafloor Fumaroles Terhadap Sebaran Suhu Permukaan dan Kondisi Lingkungan Perairan di Teluk Pria Laot, Pulau Weh. J. Segara 15:31-43. doi : 10.15578/segara.v15i1.6776

Hunt, S., Bryan, K.R., Mullarney, J.C., 2015. The influence of wind and waves on the existence of stable intertidal morphology in meso-tidal estuaries. Geomorphology 228:158-174. doi : 10.1016/j.geomorph. 2014.09 .001

llhamsyah, Y., Koesmaryono, Y., Hidayat, R., Nurjaya, I.W., Atmadipoera, A.S. \& Rizal, S., 2018. Characteristics of hydrooceanography in the Aceh waters, Indonesia: expedition by R / V. Adv. Environ. Sci. 10:200-208.

Lazure, P., Garnier, V., Dumas, F., Herry, C., Chifflet, M., 2009. Development of a hydrodynamic model of the Bay of Biscay. Validation of hydrology. Cont. Shelf Res. 29, 985-997. doi : 10.1016/j.csr. 2008.12.017

Martínez, M.L., Landgrave, R., Silva, R., Hesp, P., 2019. Shoreline Dynamics and Coastal Dune Stabilization in Response to Changes in Infrastructure and Climate. J. Coast. Res. 92, 6-12. doi : 10.2112/si92002.1

Ondara, K., Tanto, T. Al, Rahmawan, G.A., Dhiauddin, R., Wisha, U.J., 2019. HydroOceanographic and Water Quality Assesments As a Basis for the Development of Offshore Aquaculture in the Weh Island, Aceh Province, Indonesia. Aceh Int. J. Sci. Technol. 87687. doi : 10.13170/aijst.8.2.12362

Purba, N.P., Kelvin, J., Annisaa, M., Teliandi, D., Ghalib, K.G., Resti Ayu, I.P., Damanik, F.S., 2014. Preliminary research of using ocean currents and wind energy to support lighthouse in small island, Indonesia, Energy Procedia. doi : 10.1016/j.egypro. 2014.01 .215

Rampengan, R.M., 2009. Pengaruh Pasang Surut Pada Pergerakan Arus Permukaan di Teluk Manado. J. Perikan. Dan Kelaut. 5:15-19.

Rizal, S., Damm, P., Wahid, M.A., Sündermann, J., Ilhamsyah, Y., Iskandar, T., \& Muhammad, 2012. General circulation in the Malacca Strait and Andaman Sea: A numerical model study. Am. J. Environ.
Sci. doi : 10.3844/ajessp.2012.479.488

Shcherbina, A.Y., D'Asaro, E.A. \& Nylund, S., 2018. Observing finescale oceanic velocity structure with an autonomous nortek acoustic doppler current profiler. J. Atmos. Ocean. Technol. 35:411-427. doi : 1175/JTECH-D-17-0108.1

Shokri, N., Montazeri Namin, M., Farhoudi, J., 2018. An implicit 2D hydrodynamic numerical model for free surfacesubsurface coupled flow problems. Int. J. Numer. Methods Fluids 87:343-357. doi : $10.1002 /$ fld. 4494

Simatupang, C.M., Surbakti, H., Agussalim, A., 2016. Analisis Data Arus di Perairan Muara Sungai Banyuasin Provinsi Sumatera Selatan. Maspari Journal, 8:5-24.

Syaputri, M.D., Setiyono, H. \& Subardjo, P., 2016. Kajian Batimetri Untuk Penentuan Alur Pelayaran di Pelabuhan Teluk Sabang, Nangroe Aceh Darussalam. J. Oseanografi 5:148-160.

Van Rijn, L.C., 2003. Longshore Sand Transport, in: Proceedings of the Coastal Engineering Conference. pp. 2439-2451. doi : 10.1142/9789812791306_0204

Wisha, U. J., Dhiauddin, R., Gemilang, W.A., 2019. Tidal Ellipses Analysis Based on Flow Model Hydrodynamic Data Acquisition in Mandeh Bay, West Sumatera. J. Geosci. Eng. Environ. Technol. 04:93-103. olx = 25299/jgeet.2019.4.2.3115

Wisha, U.J., Husrin, S., Prihantono, J., 2015. Hidrodinamika Perairan Teluk Banten Pada Musim Peralihan (AgustusSeptember). Ilmu Kelautan: Ind. J. Mar. Sci. 20(2):101-112. doi: 10.14710/ik.ijms. 20.2.101-112

Wisha, U.J., Ondara, K., 2018a. The Influence of Nutrient ( $N$ and $P$ ) Enrichment and Ratios on Phytoplankton Abundance in Keunekai Waters, Weh Island, Indonesia. Makara J. Sci. 22:187-197. doi : 10.7454/ mss.v22i4.9786

Wisha, U.J. \& Ondara, K., 2018b. Total organic carbon and dissolved organic nitrogen in the upper water column of Keunekai Waters, Weh Island, Indonesia: An overview of mass coral mortality impacts, in: IOP Conference Series: Earth and Environ. Sci. doi: 10.1088/1755-1315/216/1 1012037

Wisha, U.J., Rahmawan, G.A., Ondara, K., Gemilang, W.A., Dhiauddin, R., Ridwan, 
N.N.H. \& Ilham, I., 2019. Offshore Floating Marine Fish Cage Aquaculture Development Planning Evaluation Based on Hydro-Oceanography Conditions in Sabang Bay, Weh Island. J. IImu Teknol. Kelaut. Trop. 11:151-162. doi: 10.29 244/jitkt.v1 1i1.24780

Wisha, U.J., Tanto, T.A., Pranowo, W.S. \& Husrin, S., 2018. Current movement in Benoa Bay water, Bali, Indonesia: Pattern of tidal current changes simulated for the condition before, during, and after reclamation. Reg. Stud. Mar. Sci. 18:177187. doi: 10.1016/j.rsma.2017.10.006

Yulianto, I., Wiryawan, B. \& Taurusman, A.A., 2017. Ecosystem Approach to Reef Fisheries Management in Weh Island, Nangroe Aceh Darussalam. Ind. Fish. Res. J. 17, 53-61. doi: 10.15578/ifrj.17.2. $2011.53-61$ 